\title{
OBITUARY
}

\section{VLADIMIR LEONOVICH KUPERMAN}

Vladimir Leonovich Kuperman, one of the leading specialists in hydropower construction, died on November 26 , 1993 after a long serious illness.

Having begun his career in 1947 and having devoted his life to the service of the country's hydropower industry, V. L. Kuperman covered the path from engineer on the Niva hydroelectric stations to deputy chief of the All-Union construction and assembly association "Soyuzgidroénergostroi."

A highly skilled specialist, V. L. Kuperman in 1967 became the chief engineer of the Main Administration for the Construction and Assembly of Hydroelectric Stations in the East (Glavvostokgidroénergostroi) and was the head of technical supervision of the construction of power facilities in the East of the country. He actively participated in the construction of the largest hydroelectric stations: Bratsk, Krasnoyarsk, Sayano-Shushenskoe, Ust'-Ilim, Nurek, Toktogul, Zeya, Ust'-Khantaika, Kureika, Shul'binsk, etc.

V. L. Kuperman is one of the authors of new designs and methods of constructing large-section hydraulic tunnels. In 1958 he successfully defended his candidate dissertation on problems of the design and construction of underground hydraulic structures. His personal contribution to improving methods and schemes of damming river channels is also considerable. Rational designs and methods of constructing dams from local materials in regions of the Far North were developed with the participation of Vladimir Leonovich and introduced under his supervision.

The outstanding work of V. L. Kuperman was highly valued by the motherland. For construction of the Nurek hydroelectric station and great contribution to the development of the power industry in Tadzhikistan, he was conferred the title "Honored Builder of the Tadzhik SSR," for active participation in the construction of the Volga-22nd Congress and Krasnoyarsk hydroelectric stations he was twice awarded Orders of the Red Banner of Labor, for construction of the Atbashi hydroelectric station he was presented with the Honorary Diploma of the Presidium of the Supreme Soviet of the Kirgiz SSR. V. L. Kuperman was twice awarded the construction prize of the USSR Council of Ministers - for participation in the creation of hydraulic structures under permafrost conditions in the Yakut ASSR and contribution to the design and construction of the multipurpose Charvak hydropower development.

Since 1952 Vladimir Leonovich also taught at the Moscow Civil Engineering Institute. He was one of the authors of a manual and textbook for the course "Economics of Hydrotechnical Construction" for institutes of higher learning.

V. L. Kuperman jointly with other authors wrote monographs: "Ust'-Khantaika Dams," "Underground Structures Under Permafrost Conditions," etc. He was the author of 65 published works and four inventions, repeatedly presented papers at international congresses and symposiums with popularization of the achievements of our hydropower industry.

He was the deputy chairman of the hydropower section of the Scientific and Technical Council of the USSR Ministry of Power and Electrification, was vice president and a member of the Soviet National Committee of the International Commission on Large Dams, a member of the Soviet committee for participation in the International Society on Rock Mechanics, and a member of the hydropower section of the All-Union Scientific and Technical Society of Power Engineers.

For many years Vladimir Leonovich was an active member of the editorial board editing hydraulic and hydropower engineering literature of the publishing house Énergoatomizdat and to his last days was a member of the editorial board of the journals Gidrotekhnicheskoe Stroitel'stvo and Énergeticheskoe Stroitel'stvo.

Profound knowledge, activity, organizational abilities, and ability to work with people - these qualities earned him the respect of the group.

The bright memory of Vladimir Leonovich Kuperman will forever remain in the hearts of those who knew him, who worked with him.

Translated from Gidrotekhnicheskoe Stroitel'stvo, No. 1, p. 54, January, 1994. 